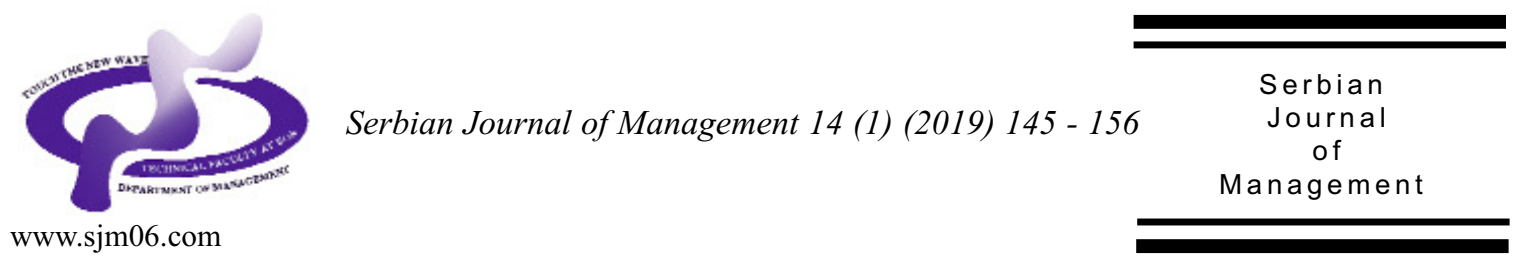

\title{
THE PHENOMENON OF MISSION IN SERBIAN COMPANIES
}

\author{
Gordana Gavrića ${ }^{\text {, Snežana Kirin }}{ }^{\text {b* }}$, Aleksandra Fedajev ${ }^{c}$, Violeta Talovićd

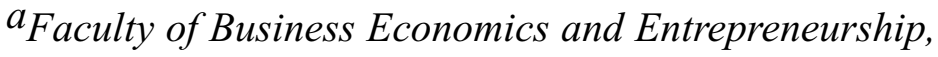 \\ Mitropolita Petra 8, 11000 Belgrade, Serbia \\ ${ }^{b}$ University of Belgrade, Innovative center, Faculty of Mechanical Engineering, \\ KraljiceMarije 16, 11000 Belgrade, Serbia \\ ${ }^{c}$ University of Belgrade, Technical Faculty in Bor, \\ Vojske Jugoslavije 12, 19210 Bor, Serbia

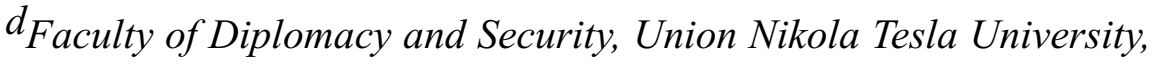 \\ Cara Dušana 62-64, 11000 Belgrade, Serbia
}

(Received 15 March 2018; accepted 7 November 2018)

\begin{abstract}
A mission statement is the personification of the organizational identity and serves as the central point for each employee to identify him-/herself with the organization. A well-defined mission ensures the stability of an organization's business as it provides a clear direction for actions and represents an important cohesion factor. Employees' behavior implied by mission is important for the achievement of the end business results; so, it is not surprising that it is considered to be a powerful tool in the management of an organization.

This paper is aimed at showing the extent to which employees are familiar with the mission of the company they work for and at pointing out the differences in understanding mission between employees in public and privately-owned companies in Serbia through carrying out an empirical research study. For the purpose of this research, a questionnaire was defined according to the Denison model and distributed indirect contact with the respondents and via the Facebook social network. The collected data were analyzed and interpreted by using descriptive analysis and the independent sample t-test. The results revealed that companies in Serbia still need to work on familiarizing their employees with mission and that there is a significant difference between state- and privately-owned companies in that respect.
\end{abstract}

Keywords: mission, organization, management, Denison model, business performances

*Corresponding author:skirin@mas.bg.ac.rs

DOI: $10.5937 /$ sjm14-16850 


\section{INTRODUCTION}

New business conditions require a modernized approach to management. The modern definition of the organization implies that it is a group of people whose operations are coordinated so as to achieve a common purpose (Cardona \& Rey, 2008). According to Cardona \& Rey (2008), the new management concept implies that people should not see their job just as "a way of earning a living", but also as a way to contribute to society and achieve selfrealization. Frank (2010) states that, today, organizations can be effective only if common values, as well as the business mission and goals, are clearly presented to their employees. MacLeod (2016), however, points out the fact that "successful organizations will be those that are steadfast in pursuit of their vision, unfailingly true to their mission and unwavering in adherence to their values". So, it can be concluded from the above-mentioned that the phenomenon of mission increasingly finds its place in the modern definitions of organizational management.

A mission is a statement on everything that an organization represents and believes in, and the reason for its existence. A clear presentation of a mission to an organization's members will motivate them to exert additional efforts and give their best to enable its achievement. In this respect, the mission statement may be the most visible and the most public part of a strategic plan (Cochran et al., 2008).

For many managers, however, a mission and a vision are plain clichés, a common statement that takes up space on the shelf after its definition. What they really need to do is extract these documents from their shelves and put them into operation as the company's compasses guiding and directing their employees' behavior. Perhaps more than ever before, a modern organization needs to know why it exists and what principles it will work on (Blanchard \& O'Connor, 2003). The careful defining of a mission is important because, if a mission is vague, or if it is just a part of an image, or if there is an absence of any, the company will be left to the mercy of market conditions.

A mission does not gain in importance when being written, published on the website, or hung on the wall, but when instilled in the minds of the organization's members instead. It should be formulated and communicated in such a manner as to be a motivation for employees and make them maximize their work efforts, which would certainly result in improving the final performances of the enterprise as a whole and achieving a competitive advantage.

In addition to the foregoing, it should be noted that not even a well-defined mission, values, and the operating system are sufficient for a success. The synchronization of employees' behavior and organizational objectives is the critical problem of management (Stojanović et al., 2013). Developing consistency towards a mission amongst employees and a clear definition of values and the business system have become the most important task delegated to the modern managers who responsibly think of the future of their organizations.

In that sense, the aim the research study sets is to determine the real state of mission as understood by the employed in organizations in the Republic of Serbia and find the ways to improve their functioning, which is especially important for stateowned companies. These companies are trying to successfully integrate into the European and world economy, but they still 
cannot leave the heritage of the centralplanning period. Doing business in that period was characterized by the absence of competitive pressures, moral hazard and a strong influence of the state on the economy. The value system in those companies has not changed much yet, for which reason there is a need for employees to become familiar with the basic concepts of doing business in market conditions, and the correct definition and understanding of the company's mission is certainly one of the most important.

\section{LITERATURE REVIEW}

Previous theoretical and practical findings in this area have shown that there is a strong positive correlation between high business results and a long-term sustainable business doing, on the one hand, and a strong sense of a mission, on the other. Thus, for example, in their paper, Smith et al., (2003) point out the fact that after the creation and presentation of a mission statement, the achievement of the company's objectives increased by $50 \%$. Carpenter \& Gong (2013), however, argue that the workers who are mission-matched produce $72 \%$ more of the output than mission-mismatched workers, where as Bart et al., (2001) found that a mission could positively influence employees' behavior, which has a direct impact on the financial results of a company.

It should be pointed out that a profit should not be emphasized in a mission statement, although it is an important goal of every company. It is important to know that beside the elements that are positively correlated with a company's performance (the adopted values, social responsibility), there are the elements that are found to be negatively correlated with performance, such as the presence of financial statement purposes (Bart \& Baetz, 1998). For that reason, the process of the development of a mission statement should be approached to with high attention and managers should be very careful about certain components they incorporate into the statement (Jovanov Marjanova \& Sofijanova, 2014).

Therefore, the behavior produced by a mission should lead to a significant increase in financial results, whereas simultaneously such increasing financial results should not stand out in the formulation of a mission. This is supported by the numerous studies demonstrating the fact that the companies that, in their missions, stated a profit as a value were less successful in achieving the same. In their studies, Dess et al. (2006) focused on testing the connectivity between corporate values and a mission, on the one hand, with the financial performance of companies, on the other, thus demonstrating that the most successful companies were those that had not mentioned a profit as a value in their mission statements, where as the less successful firms were almost entirely focused on business profitability. The reason for that is simple: a profit does not have to act as a motivator to employees, and the purpose of a mission is to present the uniqueness and resolution of a company, and inspire employees to have it implemented. In other words, a mission makes a difference between companies, explaining what its specialty is, while the maximization of a profit is a universal goal followed by each and every company, and does not have to act as a motivator.

It is important to emphasize the fact that, despite our awareness of the importance of doing business profitably, a profit cannot be the goal in itself, but rather a tool for achieving the company mission. Bart (1996) 
points out the fact that managers will probably become frustrated and disappointed if they only understand the definition of a mission as "a ticket to wealth" in achieving their company's economic goals. The results of this study have revealed that there is practically no connection between the mission and the financial operations of a company (except in a few isolated cases, which have to be fully explored). The real benefit of a mission statement arises from its impact on a company's employees' daily behavior and actions. This is a real perspective that managers should adopt in the formulation of their mission statement. In the end, Bart (1996) has concluded that a desired behavior will materialize to the extent to which mission statements are present in employees' minds- and that financial wealth should be achieved.

Based on the foregoing, a conclusion can be drawn that a modern organization will not achieve better results if they think of their business on a short-term basis, and if they are strictly focused on a profit. Their attention should primarily be focused on the formulation of a mission that will motivate their employees, integrate them into a team and direct their activities towards a common goal, which will certainly have a positive impact on the financial performance of the company. In that sense, a high level of the perceived quality of the message is positively related to employee engagement in a mission (Desmidt, 2016).However, the worrying fact is that nearly 40 percent of employees do not know or do not understand their companies' missions (Kofi Darby, 2012).

In order to clarify the current situation in Serbia, an extensive research study was conducted, and the results are going to be presented hereinafter.

\section{THE RESEARCH METHODOLOGY AND THE BASIC HYPOTHESIS}

The survey was conducted by applying the written interviewing technique. A questionnaire in the form of the Likert scale for measuring attitudes ( 1 - completely disagree, 2 - partly disagree, 3 - neither agree nor disagree, 4 - partly agree, 5 completely agree), constructed according to Denison's model (Denison \& Neale, 1999) with a slight modification of the attitudes, was used to collect data. The questionnaire was distributed in direct contact with the respondents and via the Facebook social network. The obtained data were analyzed and interpreted by applying the IBM SPSS Statistics 21program.

In its first part, the survey poses the questions related to the demographic data about the respondents, followed by the questions about the characteristics of the organization which they work in and their position in it. In the second part, the survey presents the attitudes about the mission that the employees had evaluated. The survey consists of the 15 attitudes in total, which are divided into the three large groups and refer to the Strategic Direction and Intent (There is a clear mission that gives the meaning and direction to our work; There is a long-term purpose for the company's existence, as well as a direction for its development; Our strategic direction is clear to me; There is a clear strategy for the future; Our strategy leads other organizations to change the way they compete in the industry), the Goals and Objectives (There is a widespread agreement upon the goals; Leaders set the goals that are ambitious, but realistic; The leadership has "gone on record" about the objectives we are trying to accomplish; We continuously track our progress against our stated goals; People 
understand what needs to be done for us to succeed in the long run) and the Vision (We have a common vision of what the organization will be like in the future; Shortterm thinking seldom compromises our longterm vision; Leaders think long-term; Our vision creates excitement and motivation for our employees; We are able to meet shortterm demands without compromising our long-term vision).

In order to elucidate the factors of the mission in Serbian companies, a research study was conducted on a sample of 1,000 respondents employed in different companies in 29 Serbian cities. The data were being collected during 2015. The presented results are a part of the research study of organizational culture in the Republic of Serbia's companies.

If we take a look at the structure of the sample according to the demographic characteristics, it is interesting to note that the male $(53 \%)$ and the female respondents $(47 \%)$ are fairly equally represented in the structure of the sample. The largest number of the respondents are between 31 and 40 years of age $(38 \%)$ and have a working experience ranging from 6 to 15 years $(39 \%)$. Also, most of them graduated from high school $(42 \%)$, whereas even more than onehalf of them work in executive positions (as many as 64\%).

Regarding the structure of the sample according to the characteristics of the company which the respondents are employed in, it should be said that the largest number of the respondents are employed in medium-sized companies $(33.8 \%)$ in the service sector $(20.4 \%)$. The employed in domestic companies are far more represented (even $86 \%$ of them). Apart from those who work in privately- $(52 \%)$ and state-owned companies $(44 \%)$, there are also the employees of the social enterprises (4\%) which have ceased to exist in the meantime. Namely, in 2015, when the research study had already been done, the Law on Privatization was issued, stipulating that social capital must be privatized by $31 \mathrm{st}$ December 2015, which meant that the companies of that type had ceased to exist. Some of these companies have been privatized meanwhile, where as a part of them have been nationalized.

The respondents' answers to the abovementioned groups of questions were used to test the following two research hypotheses:

1. Employees in Serbia's companies are familiar with the mission of the company they work in.

2. There are differences in the opinion about the mission between employees in state- and privately-owned companies.

In order to test Hypothesis 1, aimed at analyzing mission in the company lifecycle, a descriptive analysis was applied. In order to test Hypothesis 2, aimed at analyzing differences in the degree of mission understanding by employees in state- and privately-owned companies, the independent sample t-test was applied.

\section{THE ANALYSIS OF MISSION UNDERSTANDING BY EMPLOYEES IN SERBIAN COMPANIES}

Table 1 presents the data about the central tendency (the mean) and the standard deviation relating to the attitudes that describe the mission, for the sample size of $\mathrm{N}$ $=1000$ respondents.

According to the results presented in Table 1, it can be seen that the average score 
Table 1. Descriptive statistics

\begin{tabular}{lcc}
\hline \multicolumn{1}{c}{ Descriptive Statistics } & Mean & Std. Deviation \\
\hline $\begin{array}{l}\text { 1.There is a long-term purpose of the company existence as well as its } \\
\text { development direction }\end{array}$ & 3.99 & 1.051 \\
2.Our strategy leads other organizations to change the way they compete in the & 3.44 & 1.153 \\
industry & 3.88 & 1.133 \\
3.There is a clear mission that gives meaning and direction to our work & 3.63 & 1.210 \\
4.There is a clear strategy for the future & 3.76 & 1.222 \\
5.Our strategic direction is clear to me & 3.50 & 1.233 \\
6.Leaders set goals that are ambitious, but realistic & 3.45 & 1.175 \\
7.There is widespread agreement about goals & 3.64 & 1.247 \\
8.The leadership has "gone on record" about the objectives we are trying to meet & 3.69 & 1.161 \\
9.We continuously track our progress against our stated goals & 3.45 & 1.150 \\
10.People understand what needs to be done for us to succeed in the long run & 3.28 & 1.253 \\
11.We have a common vision of what the organization will be like in the future & 3.32 & 1.177 \\
12.Short-term thinking seldom compromises our long-term vision & 3.63 & 1.321 \\
13.Leaders have a long-term thinking & 3.14 & 1.242 \\
14.Our vision creates excitement and motivation for our employees & 3.62 & 1.093 \\
15.We are able to meet short-term demands without compromising our long-term & 3.56 & \\
vision & &
\end{tabular}

of all of the examined attitudes related to mission in the Serbian companies is approximately 3.56, which represents a slightly higher percentage compared to the attitude that the respondents neither agree nor disagree with the company mission. Having that in mind, it can be concluded that the first hypothesis can partly be confirmed. Observed as per the defined groups of attitudes, the following scores are obtained: the Strategic Direction and Intent 3.74, the Goals and Objectives 3.55 and the Vision 3.40. According to the said, it can be concluded that managers in Serbian companies should pay more attention to the definition of a vision and its presentation to their employees so as to obtain a better understanding of the mission among the employees and a greater coherence in their actions.

\section{EXAMINING THE DIFFERENCES IN MISSION UNDERSTANDING BETWEEN EMPLOYEES IN THE PRIVATE AND THE PUBLIC SECTORS}

Bearing in mind the fact that the process of transition has not been completed yet and that the strengthening of the role the private sector role plays in the economy is one of the crucial reform processes, it is important that the differences between employees in the private sector and those in the public sector regarding the understanding of mission should be examined. The market system of business doing favors private ownership over the other forms of ownership, stressing that privately-owned companies use their resources much more efficiently. Faced with strong competitive pressures, privatelyowned companies are forced to keep track of their competitors' moves and adjust their business operations to the conditions of the changing business environment in order to survive on the market. On the other hand, state-owned enterprises are far less exposed 
to the pressure of competition given the to defining the company mission, which various forms of support provided by the certainly reflects on the perceptions and state. This creates favorable conditions for performance of the employees in the the emergence of moral hazard, so managers executive function. Although the survey also in these companies give far less importance included social enterprises, which have

\section{Table 2.Descriptive statistics}

\begin{tabular}{|c|c|c|c|c|c|}
\hline \multicolumn{6}{|c|}{ Descriptives } \\
\hline & & $\mathrm{N}$ & Mean & $\begin{array}{c}\text { Std. } \\
\text { Deviation }\end{array}$ & $\begin{array}{l}\text { Std. } \\
\text { Error }\end{array}$ \\
\hline \multirow{3}{*}{$\begin{array}{l}\text { 1. There is a long-term purpose of the company } \\
\text { existence as well as its development direction }\end{array}$} & private & 520 & 4.05 & 1.020 & .045 \\
\hline & state-owned & 440 & 3.90 & 1.088 & .052 \\
\hline & Total & 960 & 3.98 & 1.053 & .034 \\
\hline \multirow{3}{*}{$\begin{array}{l}\text { 2. Our strategy leads other organizations to change the } \\
\text { way they compete in the industry }\end{array}$} & private & 520 & 3.55 & 1.091 & .048 \\
\hline & state-owned & 440 & 3.33 & 1.191 & .057 \\
\hline & Total & 960 & 3.45 & 1.142 & .037 \\
\hline \multirow{3}{*}{$\begin{array}{l}\text { 3. There is a clear mission that gives meaning and } \\
\text { direction to our work }\end{array}$} & private & 520 & 3.98 & 1.082 & .047 \\
\hline & state-owned & 440 & 3.80 & 1.159 & .056 \\
\hline & Total & 960 & 3.90 & 1.120 & .036 \\
\hline \multirow{3}{*}{ 4. There is a clear strategy for the future } & private & 520 & 3.82 & 1.173 & .051 \\
\hline & state-owned & 440 & 3.45 & 1.183 & .057 \\
\hline & Total & 960 & 3.65 & 1.191 & .039 \\
\hline \multirow{3}{*}{ 5. Our strategic direction is clear to me } & private & 520 & 3.92 & 1.125 & .049 \\
\hline & state-owned & 440 & 3.62 & 1.265 & .061 \\
\hline & Total & 960 & 3.78 & 1.200 & .039 \\
\hline \multirow{3}{*}{ 6. Leaders set goals that are ambitious, but realistic } & private & 520 & 3.72 & 1.183 & .052 \\
\hline & state-owned & 440 & 3.26 & 1.208 & .058 \\
\hline & Total & 960 & 3.51 & 1.215 & .039 \\
\hline \multirow{3}{*}{ 7. There is widespread agreement about goals } & private & 520 & 3.72 & 1.100 & .048 \\
\hline & state-owned & 440 & 3.14 & 1.170 & .056 \\
\hline & Total & 960 & 3.46 & 1.168 & .038 \\
\hline \multirow{3}{*}{$\begin{array}{l}\text { 8. The leadership has "gone on record" about the } \\
\text { objectives we are trying to meet }\end{array}$} & private & 520 & 3.86 & 1.142 & .050 \\
\hline & state-owned & 440 & 3.43 & 1.278 & .061 \\
\hline & Total & 960 & 3.66 & 1.224 & .040 \\
\hline \multirow{3}{*}{$\begin{array}{l}\text { 9. We continuously track our progress against our } \\
\text { stated goals }\end{array}$} & private & 520 & 3.87 & 1.095 & .048 \\
\hline & state-owned & 440 & 3.48 & 1.190 & .057 \\
\hline & Total & 960 & 3.70 & 1.155 & .037 \\
\hline \multirow{3}{*}{$\begin{array}{l}\text { 10. People understand what needs to be done for us to } \\
\text { succeed in the long run }\end{array}$} & private & 520 & 3.60 & 1.068 & .047 \\
\hline & state-owned & 440 & 3.28 & 1.187 & .057 \\
\hline & Total & 960 & 3.45 & 1.134 & .037 \\
\hline \multirow{3}{*}{$\begin{array}{l}\text { 11. We have a common vision of what the } \\
\text { organization will be like in the future }\end{array}$} & private & 520 & 3.51 & 1.195 & .052 \\
\hline & state-owned & 440 & 3.02 & 1.231 & .059 \\
\hline & Total & 960 & 3.29 & 1.235 & .040 \\
\hline \multirow{3}{*}{$\begin{array}{l}\text { 12. Short-term thinking seldom compromises our } \\
\text { long-term vision }\end{array}$} & private & 520 & 3.44 & 1.106 & .048 \\
\hline & state-owned & 440 & 3.17 & 1.216 & .058 \\
\hline & Total & 960 & 3.32 & 1.164 & .038 \\
\hline \multirow{3}{*}{ 13. Leaders have a long-term thinking } & private & 520 & 3.99 & 1.191 & .052 \\
\hline & state-owned & 440 & 3.24 & 1.316 & .063 \\
\hline & Total & 960 & 3.65 & 1.303 & .042 \\
\hline \multirow{3}{*}{$\begin{array}{l}\text { 14. Our vision creates excitement and motivation for } \\
\text { our employees }\end{array}$} & private & 520 & 3.33 & 1.218 & .053 \\
\hline & state-owned & 440 & 2.93 & 1.200 & .058 \\
\hline & Total & 960 & 3.15 & 1.225 & .040 \\
\hline \multirow{3}{*}{$\begin{array}{l}\text { 15. We are able to meet short-term demands without } \\
\text { compromising our long-term vision }\end{array}$} & private & 520 & 3.75 & 1.034 & .045 \\
\hline & state-owned & 440 & 3.45 & 1.123 & .054 \\
\hline & Total & 960 & 3.61 & 1.085 & .035 \\
\hline
\end{tabular}




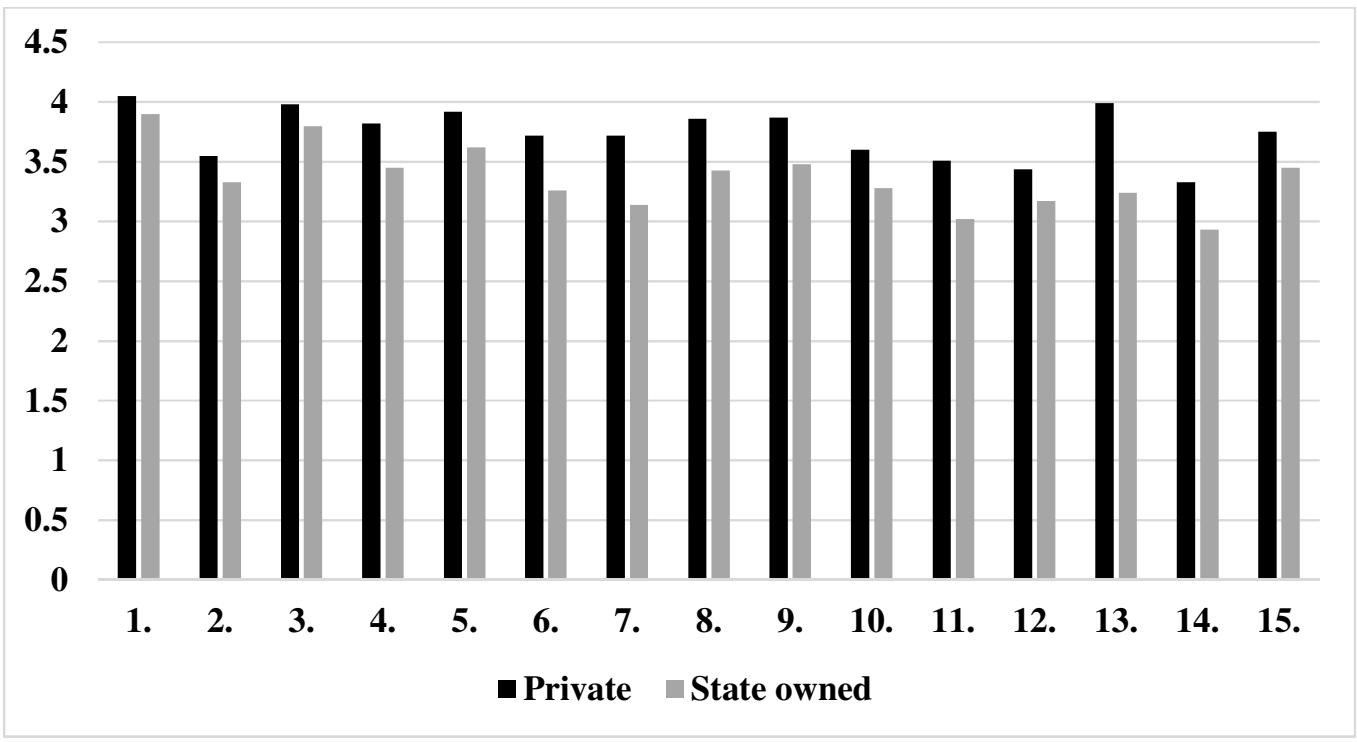

Figure 1. The responses obtained from the employees of the privately-and state-owned companies, regarding the attitudes about the mission of the company they work for

ceased to exist in the meantime, those enterprises were omitted in the further processing of the data, with an emphasis being placed on the state and privatelyowned companies.

Table 2 accounts for the descriptive statistics for all of the attitudes in the stateand privately-owned companies.

The data accounted for in Table 2 are undoubtedly indicative of the fact that the average score for all of the attitudes, and therefore the awareness and understanding of the mission, is higher amongst the employees in privately-owned companies than with those employed in the state-owned ones. In order to more obviously show the differences in the responses between the respondents from the privately- and stateowned companies, the obtained results are shown in Figure 1. The attitudes are marked with the regular numbers they are noted in Table 2.

Bearing in mind the fact that the score for each and every analyzed statement is higher in the privately-owned companies than in those state-owned, the average value of the score for all of the statements is consequently higher for the privately-owned companies (3.74) compared to those owned by the state (3.36).

Table 3 reveals the results of the t-test for independent samples. The first part of the table shows the results of Leven's test of the variances equality. The outcome of this test determines whether the t-value is used when the equality of the variance (Sig $>0.05$ ) or the t-value is implied, when the equality of the variance $(\operatorname{Sig}<0.05)$ is not implied.

The results of independent samples t-test provided in Table 3 point out the statistically significant differences in all the statements related to the mission in the state- and privately-owned companies. This means that, based on the results, it can be concluded that there is a better awareness of the mission amongst the employees of the privatelyowned companies. 
Table 3.The results of the Independent Samples Test

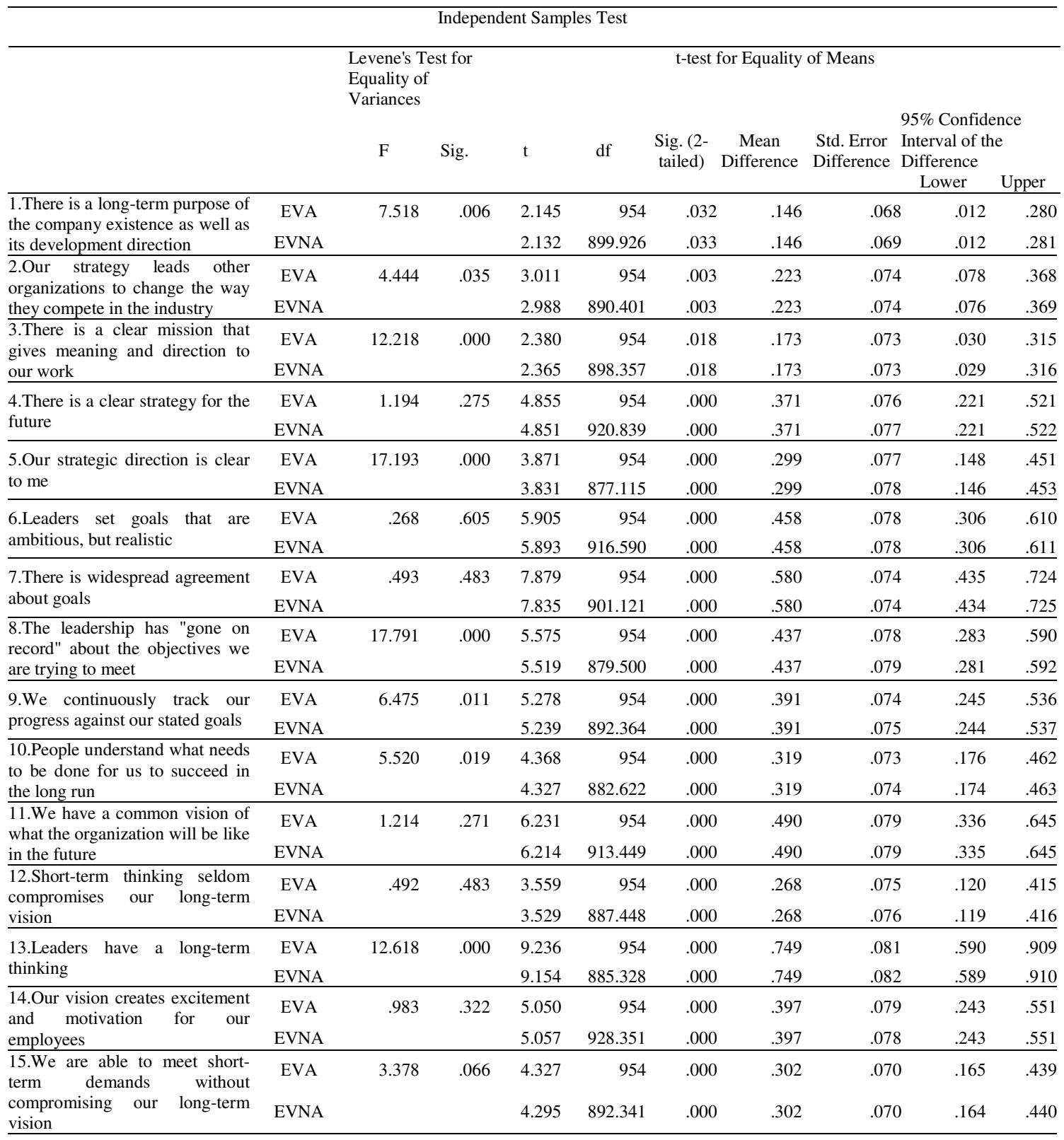

\section{CONCLUSION}

Building a high degree of unity through the establishment of trust and commitment between an organization and its employees has become a task of the greatest importance delegated to the managers who responsibly think of the future of the organization. This activity carried out by the management of a company has a slight priority over the other ones because if unity falls below a certain level, the organization will start to decompose until it has died, similarly to any organism the harmony of whose functioning has been done harm. In other words, at a time when business doing is considered to be a 
kind of hazard, a mission is viewed as the mechanism that keeps the members of an organization together, showing them the right direction to follow in conducting their actions, with the ultimate goal of turning their vision into reality. In that sense, and according to the Denison model, a mission with a clearly defined strategic direction, goals and vision can be said to represent a statement, whose application should lead to the desired behavior of the company's employees and its desired financial results.

Based on the obtained results in this research study, it can be concluded that the first hypothesis that employees in Serbia are familiar with mission is only partly verified given the fact that the mission-related average score amounts to 3.56, which indicates a slightly higher value than the neutral attitude (neither familiar nor unfamiliar). Since a mission is only considered as worthy when all employees are familiar with it and when it is deeply embedded in their minds, one of the recommendations for managers in Serbia is that they should do something in order to make their employees aware of the company's purpose and its business principles that are deemed to be basic.

The other hypothesis of the differences in mission-related attitudes in privately- and state-owned companies has been confirmed. Employees in privately-owned companies are forced to be more committed to the work they do since the financial performance of the companies they are employed in depends on their commitment, where as in stateowned companies there is a stable inflow of financial assets, for which reason their employees do not have the same working habits. Managers of a state-owned company must, first of all, understand the importance of a well-defined and properly presented mission, and then ensure that their employees become familiar with the company's mission, the phenomenon that allows an organization to manage its own future, survive in crisis situations, and obtain significant financial results.

Also, it should be noted that the importance of the conducted research study lies in the fact that it was conducted on a sample of 1000 respondents from 29 cities, which enhances the credibility of the obtained conclusions. The observed differences regarding the mission-related aspects can serve as a direction for improving the performance of both state- and privately-owned companies, bearing in mind the fact that, despite the higher average score recorded in the privately-owned companies, there is plenty of room for improvement in this segment of the economy because only in one attitude (There is a long-term purpose for the company's existence, as well as a direction for its development) is the acquired value just above 4 , which would correspond to the fact that the employees partly agree upon the examined attitude.

It can be concluded that organizations in the Republic of Serbia need a transformation of the existing organizational culture where mission is an important factor. These transformations are the response to the changes of the paradigm in wider environment and are necessary for a longterm survival of organizations.

The limitation to this research is an unequal number of interviewees from state and private owned companies.

Presented results offer the possibility of creating real image of the mission phenomenon in companies in the Republic of Serbia. Importance of this paper is in the research results themselves because there have been no similar research activities so 
far and they are useful for the promotion of companies' work which, in the transition period, are trying to enter the global market. Future research papers could include results of the mission phenomenon in relation to other characteristics of organizations and employees such as: ownership structure,size, position of employees within a company, years of service, age structure, professional qualifications level, company's field of work, in order to gain a more complete picture of the awareness of employees about the mission inside their companies and to draw comprehensive conclusions and recommendations.

\section{ФЕНОМЕН МИСИЈЕ У СРПСКИМ КОМПАНИЈАМА}

\section{Гордана Гаврић, Снежана Кирин, Александра Федајев и Виолета Таловић}

\section{Извод}

Изјава о мисији је персонификација идентитета организације и служи као основа за све запослене да се идентификују са организацијом. Добро дефинисана мисија обезбеђује стабилност организације јер даје јасан правац кретања и представља значајан кохезиони фактор. Понашање запослених, које она производи, значајно је за остваривање крајњих резултата у пословању, па је зато са правом сматрају моћним алатом у управљању организацијом.

Циљ овог рада је показати, кроз емпиријско истраживање, у којој мери су запослени упознати са мисијом компаније у којој раде и уочавање разлика у схватању мисије између запослених у јавним предузећима и приватним компанијама. За потребе истраживања поменуте теме формулисан је упитник у складу са Денисоновим моделом и дистрибуиран је испитаницима у директном контакту, као и путем друштвене мреже “Facebook". Прикупљени подаци су анализирани и тумачени коришћењем дескриптивне статистике и т-теста за независне узорке. Резултати указују на то да компаније у Србији треба да се труде да боље упознају запослене са мисијом компаније и да постоје значајне разлике између јавних и приватних предузећа у том смислу.

Кључне речи: мисија, организација, менаџмент, Денисонов модел, пословни резултати

\section{References}

Bart, C.K. (1996). Industrial firms \& the power of mission. C.A. Innovation Research Working Group, working paper no. 48, MINT (Management of Innovation and New Technology) Research Centre Working Paper Series, 1-30.

Bart, C.K., \& Baetz, M.C. (1998). The relationship between mission statements and firm performance: An exploratory study.
Journal of Management Studies, 35(6), $823-853$.

Bart, C.K., Bontis N., \& Tagger, S. (2001). A model of the impact of mission statements on firm performance. Management Decision, 39(1), 9-18.

Blanchard, K., \& O'Connor, M. (2003). Managing by Values: How to Put Your Values Into Action foe Extraordinary Results -2nd edition. Berrett-Koehler Publishers, San Francisko. 
Cardona, P., \& Rey, C. (2008). Smith, M., Heady, R.B., Carson, P.P., \& Management by missions. Palgrave Carson, K.D. (2003). Do Missions Macmillan, UK. Accomplish their Missions? An Exploratory

Carpenter, J., \& Gong, E. (2016). Motivating Agents: How Much Does the Mission Matter?. Journal of Labor Economics, 34 (1), 211- 236.

Cochran, S.D., David, R.F., \& Gibson, C.K. (2008). A Framework for Developing an Effective Mission Statement. Journal of Business Strategies, 25 (2), 27-39. Analysis of Mission Statement Content and Organizational Longevity. Journal of Applied Management and Entrepreneurship, 6(1), 75-96.

Stojanović, T., Đokić, A., \& Đokić, S. (2013). Organizational Behavior-Creative Tool for Creating Value. International Review, (1-2), 69-82.

Denison, R.D., \& Neale, S.W. (1999). Denison Organizational Culture Survey, Facilitator Guide. Denison Consulting, LLC.

Desmidt, S. (2016). The relevance of Mission Statements; Analyzing the antecedents of Perceived message quality And its relationship to Employee mission Engagement. Public Management Review, 18 (6), 894-917.

Dess, G.G., Lumpkin, G.T., \& Eisner, A.B. (2006). Strategic management: Text and cases (2nd ed.). New York, NY: McGraw-Hill Irwin. Frank, A. (2010). Management - Von den Besten lernen,Carl Hanser Verlag $\mathrm{GmbH} \& \mathrm{Co}$, Munich (in German).

Jovanov Marjanova, T., \& Sofijanova, E. (2014). Corporate Mission Statement and Business Performance: Through the Prism of Macedonian Companies. Balkan Social Science Review, 3, 179-199.

Kofi Darbi, W. P. (2012). Of Mission and Vision Statements and Their Potential Impact on Employee Behaviour and Attitudes: The Case of A Public But ProfitOriented Tertiary Institution. International Journal of Business and Social Science, 3(14), 95-109.

MacLeod, L. (2016). Mission, vision and values statements: The physician leader's role. Physician Leadership Journal, 3(5), 1825. 